\title{
Geochemical Changes in Aquatic Environment Caused by Deep Dredging - A Case Study: The Puck Bay (Baltic Sea)
}

\author{
Bożena Graca ${ }^{1}$, Katarzyna Łukawska-Matuszewska ${ }^{1}$, \\ Dorota Burska ${ }^{1}$, Leszek Łęczyński and Jerzy Bolałek ${ }^{1}$ \\ ${ }^{1}$ Institute of Oceanography, University of Gdańsk, Gdynia, \\ ${ }^{2}$ Maritime Institute in Gdansk, Gdansk, \\ Poland
}

\section{Introduction}

Dredge activities is very widespread antropogenic seabed disturbance. It is used to replenish sand on beaches, to create and maintain harbor, berth, waterways, may also be used for underwater mining activities and as a technique for fishing certain species of crabs or edible clams. Dredging has many deleterious environmental effects (Johnston 1981). Changes in bottom topography due to dredging can influence water dynamic and in consequence sediment transport (Maa et al., 2004; Work at al. 2004). Dredge pits and deep furrows can create a sink for fine-grained sediments, organic matter and contaminants (Desprez 2000) and result in hypoxic and anoxic conditions, as well as sulfate reduction in sediment (Bolałek et al., 1996, Flocks\&Franze 2002, Graca at al. 2004) (Fig. 1). Geochemical changes resulted in deep dredging can affect benthic organisms. Limited recolonization of dredge pits was observed (Palmer et al. 2008, Szymelfenig et al. 2006). Such condition can influence nutrients dynamic and potentially stimulate eutrophication (Graca et al., 2004).

Impact of dredging depends on its intensity and the type of used method, as well as the environmental condition in dredge area (Boyd et al. 2005, Robinson et al. 2005). Puck Bay is a small water body located on the Polish Baltic coast. Deep dredging works carried in this reservoir, creates great opportunity to study the impact of deep dredging in areas with different water dynamics. From the north the bay is restricted from the open Baltic by the Hel Peninsula. It is $34 \mathrm{~km}$ long, and its width varies from $0.2 \mathrm{~km}$ to $2.9 \mathrm{~km}$. A change of peninsula land cover during the last few decades, especially the construction of the new harbor, enhanced erosion processes. At present, the Hel Peninsula requires intensive reinforcement (Urbański \& Solanowska, 2009). Eighty-two percent (c.a. 6,98 $\mathrm{mln} \mathrm{m}^{3}$ ) of sands for peninsula's bank protection was gained from the bottom of the Puck Bay. First large beach nourishment was carried out by the end of 80 's in last century. As an effect, in the years 1989-95, five the dredge pits were created in the bottom of the Puck Bay along the Hel Peninsula (Fig.2). The depth of the pits reaches 7-14 m, while natural depth in the surrounding area does not exceed $2 \mathrm{~m}$. 
a)

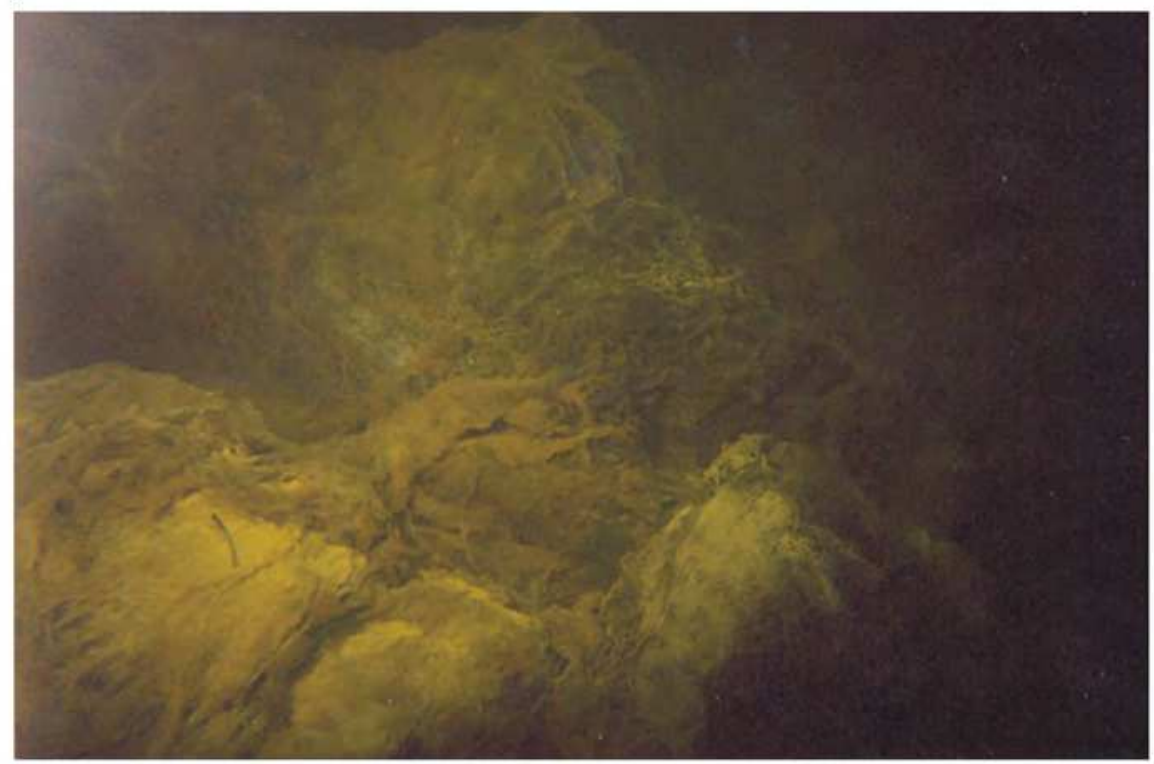

b)

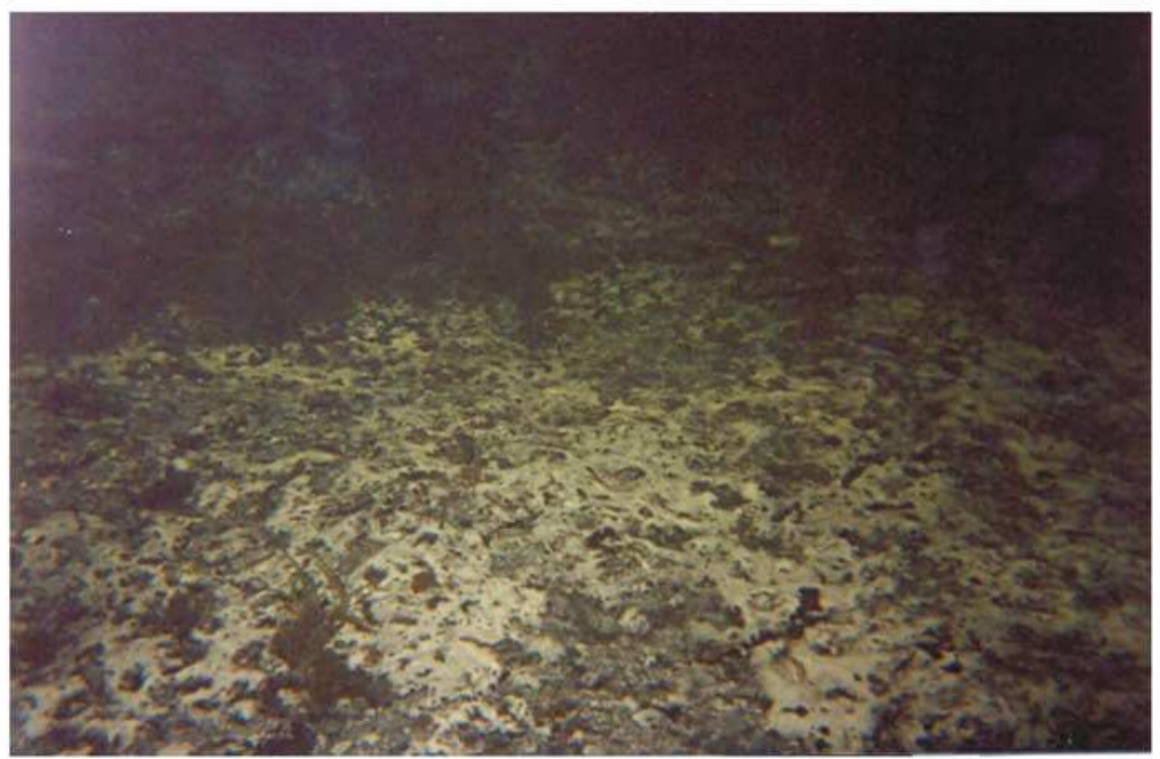

Fig. 1. Bottom at the deep part of the dredge pit in the Puck Bay. Photos made in Władysławowo dredge pit (a) in full growing season and (b) at the end of growing season. 


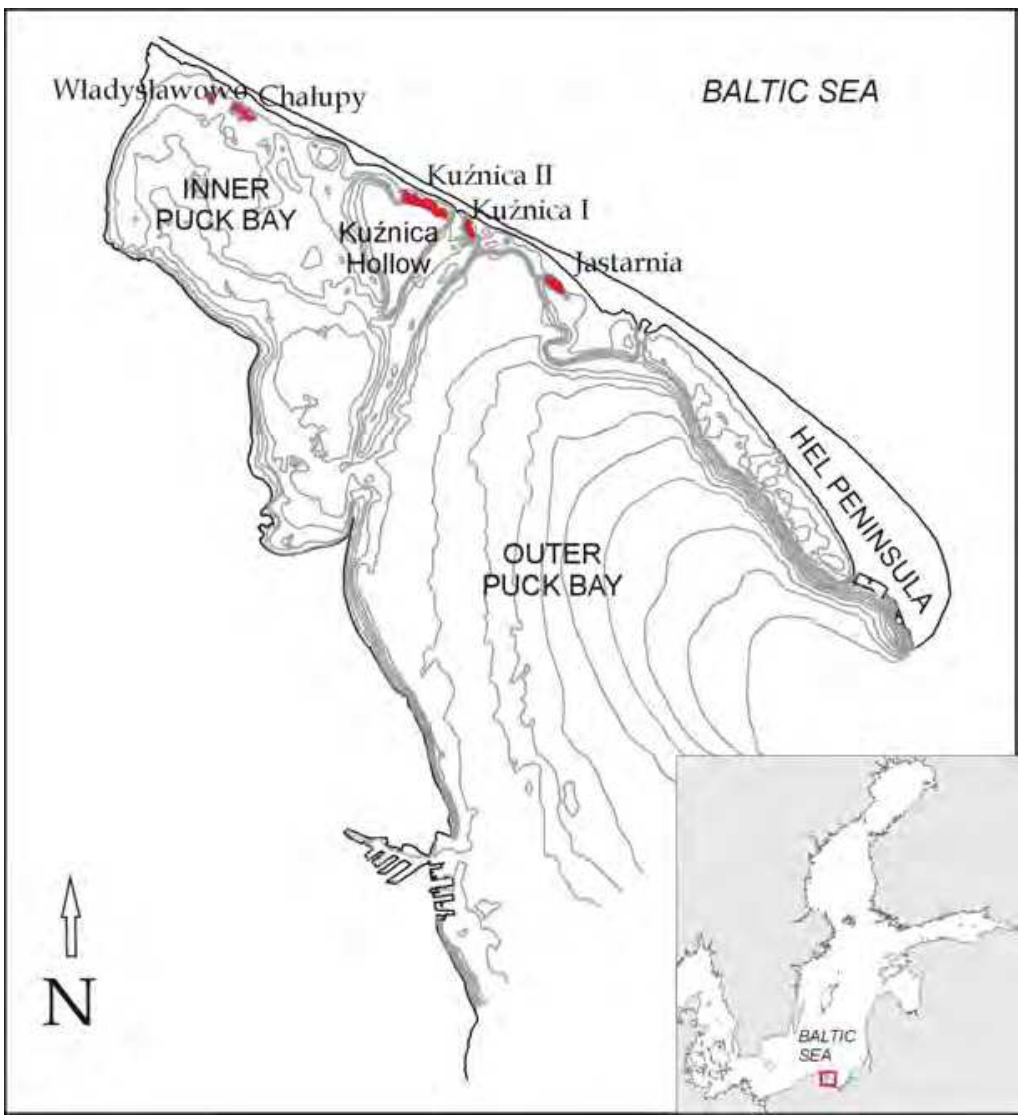

Fig. 2. Location of dredge pits in the Puck Bay.

Dredging for marine minerals has occurred in Poland waters for many years, in response to the need for sand and gravel used as construction aggregate and for beach replenishment. The first attempt to take account of environmental aspects of sands excavation from the bottom of the Puck Bay has been taken in 1992. Ciszewski and Kruk-Dowgiałło (1992) in their evaluation including some biological (phyto- and zoobentos), microbiological (bacterioplancton) and chemical (oxygen conditions) aspects suggested that, dredging should not be deeper then $3 \mathrm{~m}$. It is necessary in order to reproduce disturbed biocenosis. But this suggestion was not obligatory. Currently, based on legal requirements the Environmental Impact Assessment is required (including the development of Environmental Impact Report) in the case of projects with potentially significant impacts on natural environment.

The Puck Bay is a protected area, in the frame of the European Ecological Natura 2000 Network (birds directive and habitat directive). Its northern part, containing the dredge pits, is included in the Seaside Landscape Park - a national protected area. According to EU Water Framework Directive, Poland should provide an improvement of quality of sea waters, especially in the protected areas. 
Despite the research conducted so far in two of the dredge pits (Bolałek et al. 1996, Graca et al. 2004, Graca \& Dudkowiak 2006, Szymelfenig et al. 2006), it is not known, which pits in the Puck Bay have undergone the largest changes in respect to natural conditions, what is the season influence on environmental conditions in the pits, and what is the scale of the problem created by the geochemical changes in bottom sediments of pits? An aim of this work is answering these questions. This is necessary to decide about the eventual recultivation of the dredge pits, and to choose a way to conduct it. Results of this study can be additionally used during the planning stage of environment-friendly dredging work.

\section{Materials and methods}

Samples of sediments, nearbottom and interstitial waters were collected by means of scuba diving in November-December 2007, in March, May-June and in August 2008.

Nearbottom waters were collected to glass and polyethylene bottles. Interstitial waters from the surface sediment layer (c. $4-5 \mathrm{~cm}$ ) were obtained in situ by means of syringe tipped with pumice stone. This method detailed description has been given in Graca et al. (2004). Sediments ( 3 cores at each station) were sampled with Plexiglas pipes, $30 \mathrm{~cm}$ long and 3.6 $\mathrm{cm}$ in diameter (Fig. 3)

In each of the five studied the dredge pits (Fig. 2) samples were collected in three locations: in shallow parts of the slopes (stations S1), in deep parts of the slopes (stations S2) and at the bottom of the pit (stations D) (Fig. 4). Additionally samples were collected at two stations located on the outskirts (stations labeled O). One of those stations was situated between the dredge pit and the peninsula (labeled OP), and the other between the pit and the bay (OZ) (Fig. 4).

Ammonia, phosphates and hydrogen sulfide were analyzed in nearbottom and interstitial waters (Grasshoff et al. 1983). Oxygen in the nearbottom water has been determined by titration (Strickland \& Parsons, 1972).

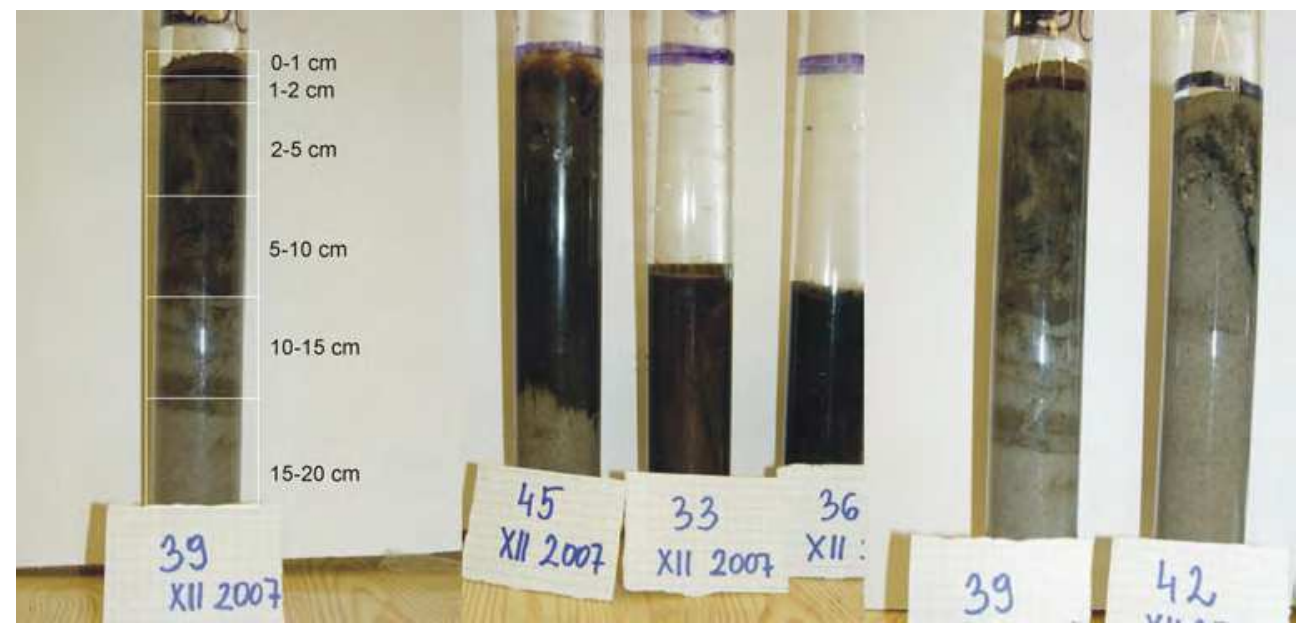

Fig. 3. Sediment cores collected in dredge pits (scheme of core division). 
Sediment cores of maximum length of $20 \mathrm{~cm}$ were divided into six layers: $0-1 \mathrm{~cm}, 1-2 \mathrm{~cm}, 2-5$ $\mathrm{cm}, 5-10 \mathrm{~cm}, 10-15 \mathrm{~cm}$ and 15-20 cm (Fig. 3). In those layers moisture content (W) and loss on ignition (LOI) has been determined by drying the sample to constant mass. Samples were dried in first case at $105^{\circ} \mathrm{C}$, in the latter in $550^{\circ} \mathrm{C}$.

Organic carbon $\left(\mathrm{C}_{\mathrm{org}}\right)$ and total nitrogen $\left(\mathrm{N}_{\text {tot }}\right)$ contents were measured using the Perkin Elmer $2400 \mathrm{CHNS} / \mathrm{O}$ analyzer. Sediment samples were dried at $60^{\circ} \mathrm{C}$ until reaching a constant mass. Samples for organic carbon determination were treated with $1 \mathrm{M} \mathrm{HCl}$ in order to remove carbonates (Hedges\& Stern, 1984, Burska, 2010).

Total phosphorus $\left(\mathrm{P}_{\mathrm{tot}}\right)$ has been determined by spectrophotometry using acid-molybdate method after previous ignition $\left(24 \mathrm{~h}\right.$ in $\left.483^{\circ} \mathrm{C}\right)$ and leaching with $1 \mathrm{M}$ hydrochloric acid. Inorganic phosphorus $\left(\mathrm{P}_{\text {inorg }}\right)$ has been analyzed in similar way, but without ignition. Organic phosphorus $\left(\mathrm{P}_{\text {org }}\right)$ concentration has been calculated as a difference between $\mathrm{P}_{\text {tot }}$ and $P_{\text {inorg }}$ (Froelich et al., 1988).

Chlorophyll $a$ (chl $a$ ) and pheophytin (pheo) contents in sediment were determined by applying the method developed by Plante-Cuny (1974). Lyophilized sediment samples were homogenized and later extracted with $90 \%$ acetone for 8 hrs. Spectrophotometric measurements of extinction in extract samples were performed before and after acidification with $1 \mathrm{M} \mathrm{HCl}$. Redox potential (Eh) and $\mathrm{pH}$ were measured by means of electrodes.

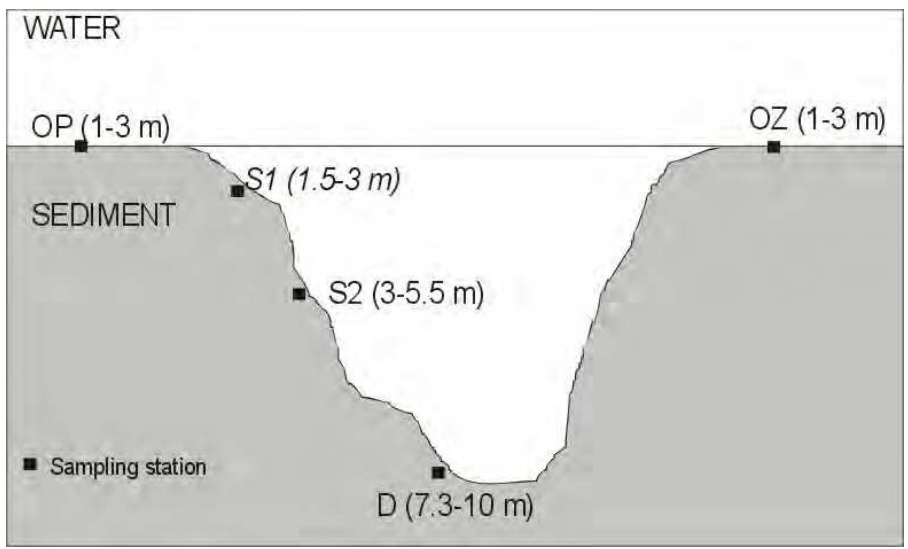

Fig. 4. Sampling stations arrangement in the dredge pits and at their outskirts.

\section{Results}

\subsection{Nutrients, oxygen and hydrogen sulphide in nearbottom and interstitial waters}

Nearbottom waters in the study area were characterized with good oxygen conditions. The lowest oxygen concentrations $\left(4,1 \mathrm{~cm}^{3} \mathrm{dm}^{-3}\right)$ were observed at the outskirts of the Władysławowo pit in December. Decreased oxygen concentrations were also noticed in spring in the deepest parts of the Władysławowo $\left(4,8 \mathrm{~cm}^{3} \mathrm{dm}^{-3}\right)$ and Chałupy $\left(5,8 \mathrm{~cm}^{3} \mathrm{dm}^{-3}\right)$ pits.

Concentrations of phosphates $\left(0,0-3,9 \mu \mathrm{mol} \mathrm{dm}^{-3}\right)$ and ammonia $\left(0-4,1 \mu \mathrm{mol} \mathrm{dm}^{-3}\right)$ in the nearbottom waters at the outskirts and inside the pits did not differ significantly and were similar to those observed in the Puck Bay (Bolałek et al. 1993).

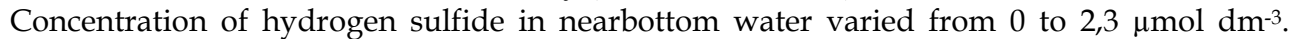

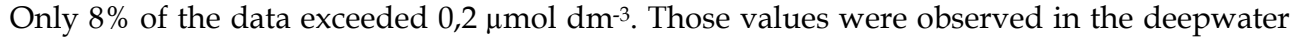


parts of the Władysławowo pit (November-December and August), Chałupy pit (November-December and May), Kuźnica I (November-December, May-June) and Kuźnica II pit (November-December), and also on the shallow slope of the Jastarnia pit (NovemberDecember).

In the interstitial waters hydrogen sulfide concentration varied in range $0-88,7 \mu \mathrm{mol} \mathrm{dm}-3$ (Fig. 5a). The highest values occurred in the deepwater part of the dredge pits. $79 \%$ of the data did not exceed $10 \mu \mathrm{mol} \mathrm{dm}{ }^{-3}$. Concentrations higher than $10 \mu \mathrm{mol} \mathrm{dm}{ }^{-3}$ were observed in August, and additionally in the Władysławowo pit also in May-June (stations O, S2 and D), and in March (station D).

Phosphate concentrations in the interstitial waters ranged from 0,2 to $58,3 \mu \mathrm{mol} \mathrm{dm}^{-3}$ (Fig.

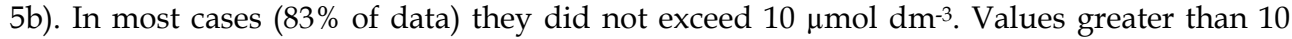
$\mu \mathrm{mol} \mathrm{dm}{ }^{-3}$ were observed in August in the deepwater part of all the dredge pits (stations D and S2) and additionally at the shallow slope (stations S1) of the Władysławowo, Kuźnica I and Jastarnia pits. In the interstitial waters from the bottom (station D) of the Władysławowo pit, phosphate concentrations exceeding $10 \mu \mathrm{mol} \mathrm{dm}-3$ occurred also in March and in May-June.
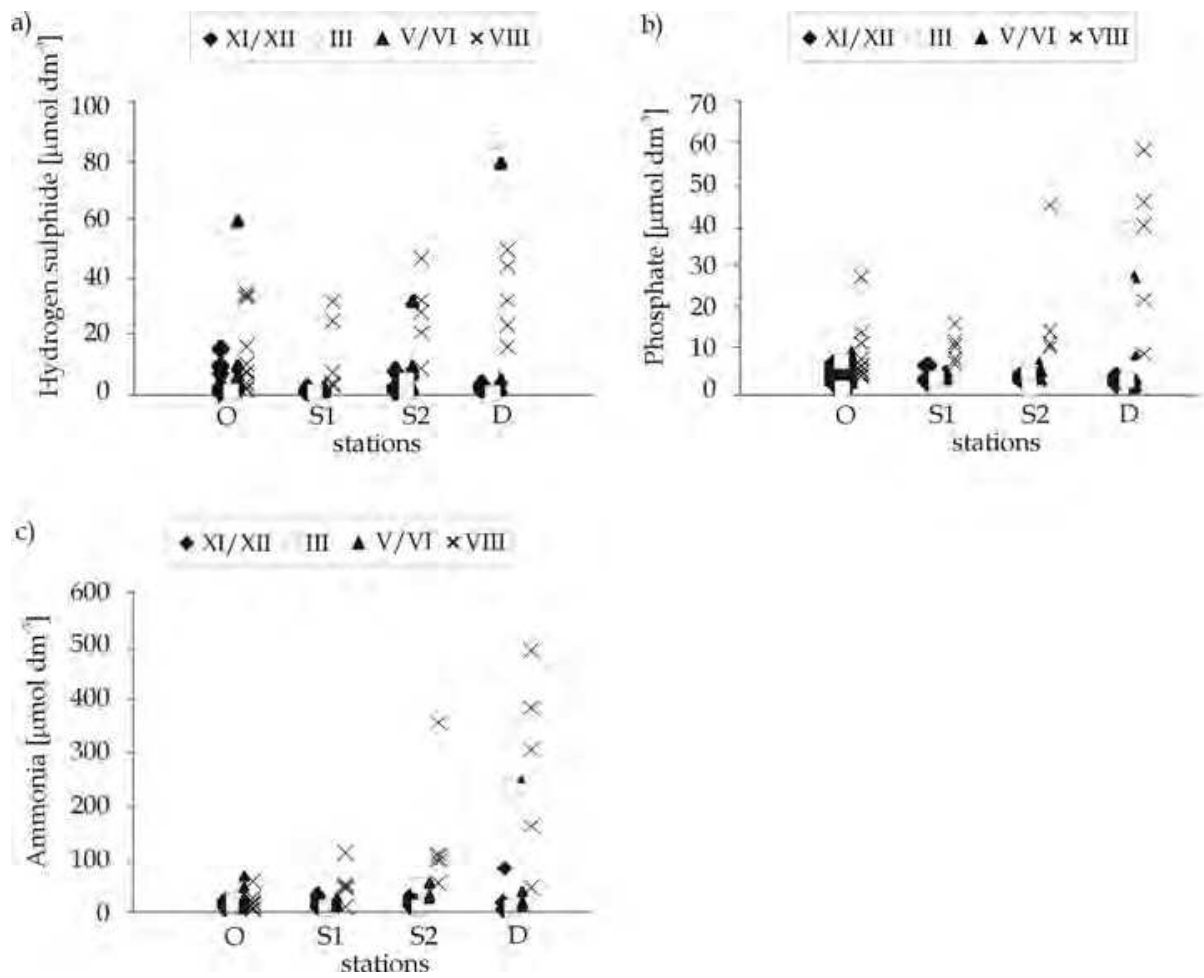

Fig. 5. Concentrations of (a) hydrogen sulfide, (b) phosphates and (c) ammonia in the interstitial waters observed in particular sampling seasons at the outskirts of the dredge pits (O), at their shallow (S1) and deeper (S2) slopes, and at the bottom (D). 
Ammonia concentrations in the interstitial waters varied from 3,5 to $389,1 \mu \mathrm{mol} \mathrm{dm}{ }^{-3}$ (Fig. $5 \mathrm{~b})$. Majority of the results (89\% of data) did not exceed $100 \mu \mathrm{mol} \mathrm{dm}-3$. Concentrations higher than $100 \mu \mathrm{mol} \mathrm{dm}{ }^{-3}$ were observed in August in the deepwater parts of all the dredge pits (stations S2 and D), and in the Władysławowo pit additionally at the shallow slope (station S1). At the center (station D) of the Władysławowo pit ammonia concentrations exceeding $100 \mu \mathrm{mol} \mathrm{dm}{ }^{-3}$ were also noticed in March and May-June

\subsection{Sediments}

\subsubsection{Grain size distribution, W, LOI, Eh and phosphorus}

An increase of the fine sediment fractions has been observed $(<125 \mu \mathrm{m})$ in the dredge pits sediments in comparison to their outskirts (Fig. 6). This increase was most pronounced in the deepest parts of the dredge pits (stations D). Except the Jastarnia and Chałupy pits, it was also visible on the slopes. It has to be noted that content of fractions $125 \mu \mathrm{m}$ and $63 \mu \mathrm{m}$ in the sediments of the Władysławowo pit's outskirts were clearly higher than this found at the other outskirts.

Three quarters of the moisture content results in the sediments of the outskirts did not exceed $20 \%$ (Tab. 1). Moisture content has increased in the dredge pit areas. Sediments in their deepest parts (station D) were most hydrated (Fig. 7). Only quarter of the moisture content results in these areas were below $26 \%$. LOI variability has been similar (Tab. 1, Fig. 8).

Outskirts (stations O) and slopes (stations S1 and S2) of the dredge pits did not differ significantly in regard to phosphorus content in the sediments (Tab. 1). Clearly higher concentrations were observed at the bottom (stations D) of the pits.

Redox potential of the sediments varied from (-495) to $489 \mathrm{mV}$ (Tab. 1). In the deepwater part of the pits (stations S2 and D), in approximately half of the cases, sediments were reductive (Eh<100 $\mathrm{mV}$ ) from the first analyzed layer. Reductive conditions intensified with depth below the sediment surface (Fig. 9). Below the topmost centimeter of sediment, $82 \%$ of the results were lower than $100 \mathrm{mV}$.

At the outskirts (stations O) and at the shallow slope of the dredge pits (stations S1) reductive conditions occurred in $15 \%$ of the cases. In half of the cases they appeared in the sediment layer below the $0-2 \mathrm{~cm}$.

Outskirts (stations O), slopes (stations S1 and S2) and the centers of the dredge pits (stations D) were similar in regard to $\mathrm{pH}$ in the sediments (ANOVA Kruskall-Wallis test, $\mathrm{p}=0,61, \mathrm{Tab} .1$ )

\subsubsection{Organic carbon, total nitrogen and photosynthetic pigments}

Organic carbon contents in the analyzed sediment ranged from 0,021 to $168,50 \mathrm{mg} \mathrm{g}^{-1} \mathrm{~d} . \mathrm{w}$., while the median (Md) value was $1,52 \mathrm{mg} \mathrm{g}^{-1} \mathrm{~d} . w$. (Tab. 2). Most of $\mathrm{C}_{\text {org }}$ concentration values $(75 \%)$ were lower than $3,42 \mathrm{mg} \mathrm{g}^{-1} \mathrm{~d} . \mathrm{w}$. Total nitrogen concentration values were ca. 10 times lower and ranged from 0,01 to $22,11 \mathrm{mg} \mathrm{g}^{-1} \mathrm{~d}$.w. (Tab. 2).

Similarly to $\mathrm{C}_{\text {org }}$ concentration values, high values of $\mathrm{N}_{\text {tot, }}$ i.e. $>0,45 \mathrm{mg} \mathrm{g}^{-1} \mathrm{~d}$.w. constituted only $25 \%$ of all measurements.

Chlorophyll $a$ concentrations varied from the value equal to the limit of detection (LD) to $124,12 \mu \mathrm{g} \mathrm{g}-1$ d.w., while the median value was $0,35 \mu \mathrm{g} \mathrm{g}-1 \mathrm{~d}$.w. Most of $\mathrm{chl} a$ concentrations (75\%) were lower than $1,42 \mu \mathrm{g} \mathrm{g}-1 \mathrm{~d}$.w. Phaeopigment concentrations were on average six times higher than the concentrations of chlorophyll $a$ (Tab. 2). 

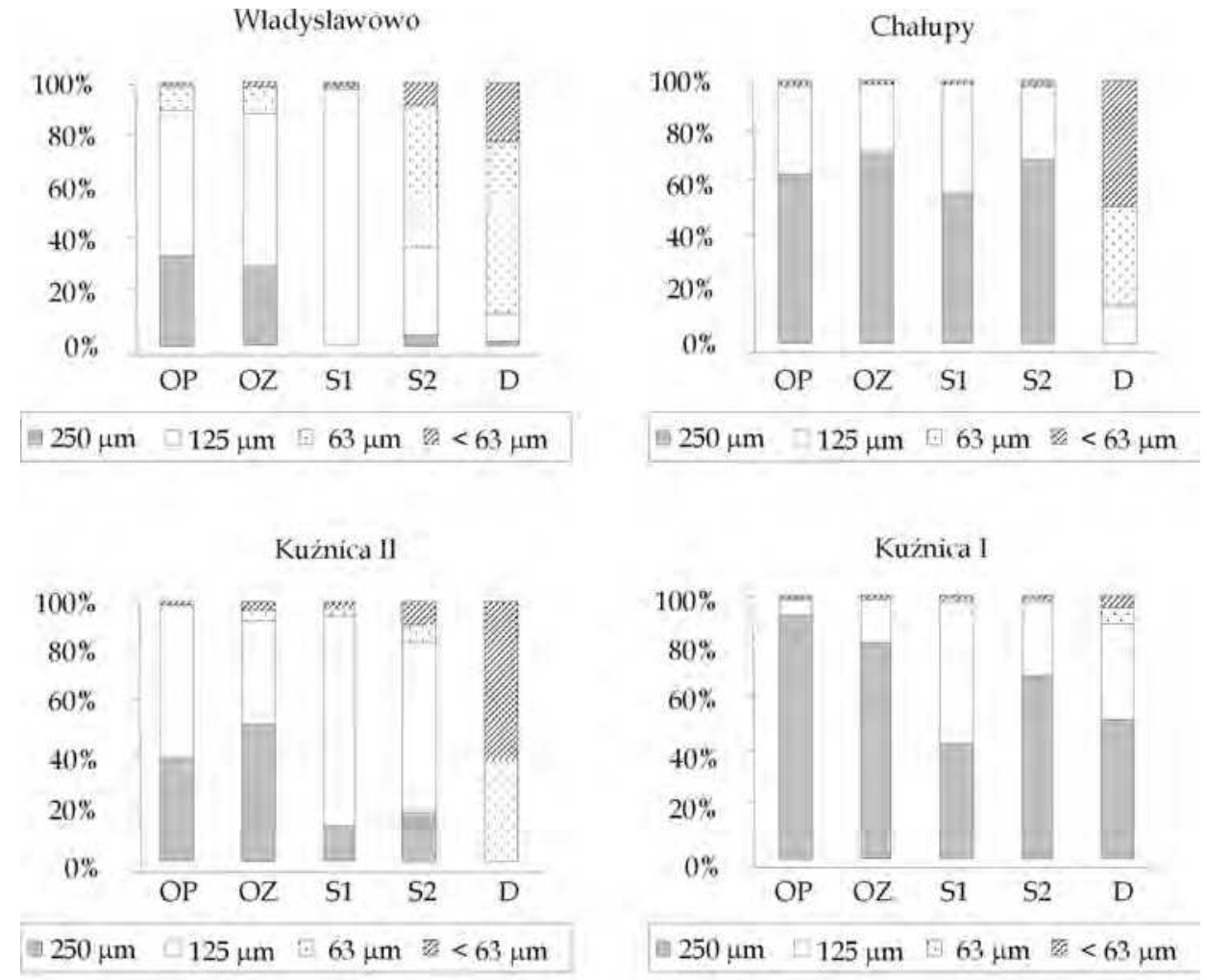

Jastarnia

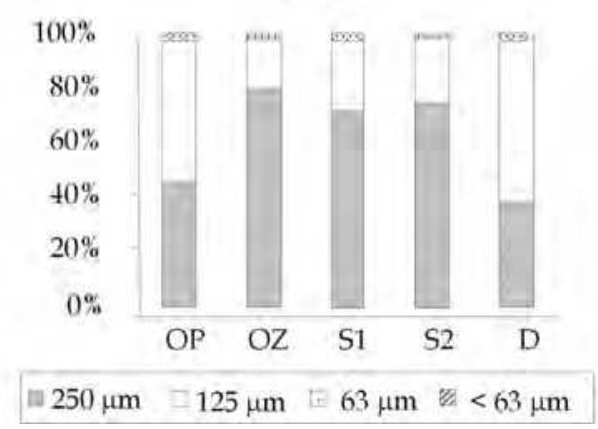

Fig. 6. Contribution of different sediment fractions (in the topmost layer - $0-5 \mathrm{~cm}$ ) in the dredge pits and at their outskirts (OP - outskirt of the pit, peninsula side, OZ - outskirt of the pit, bay side, S1 - shallow slope, S2 - deep slope, D - bottom of the pit). 
a)

WLADYSLAWOWO

Median; Box: $25 \%-75 \%$; Whisker: Non-Outlier Range

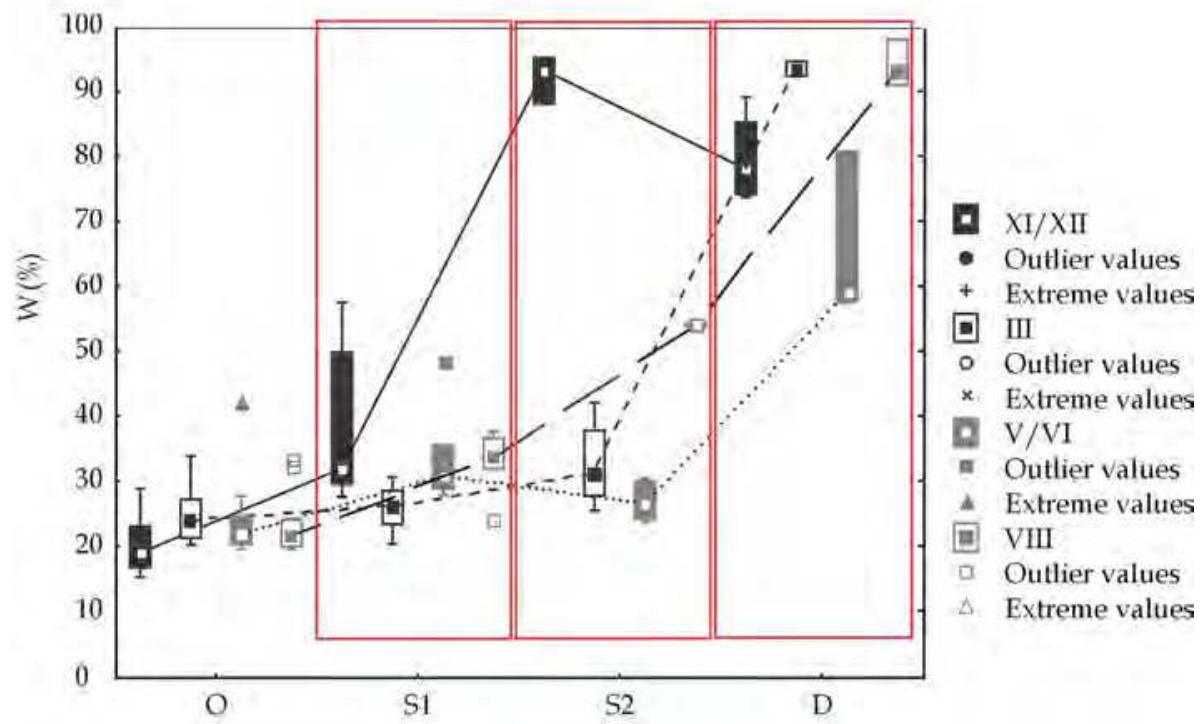

b)

JASTARNIA

Median; Box; $25 \%-75 \%$; Whisker: Non-Outlier Range

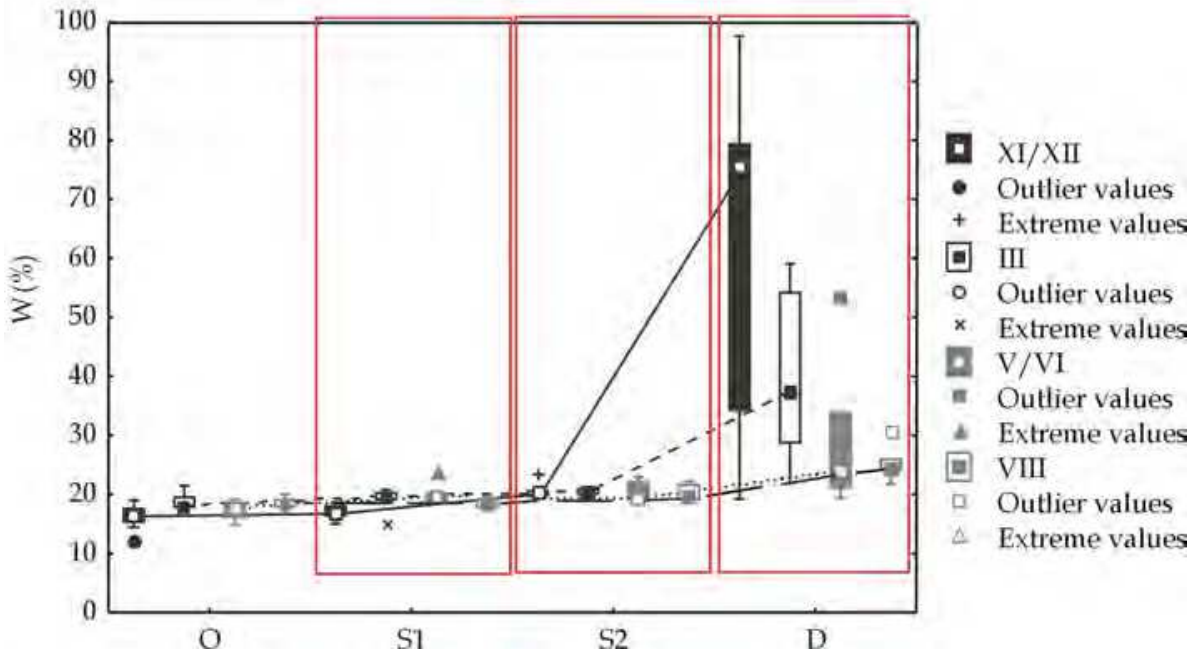

Fig. 7. Seasonal variation in sediment moisture content $(\mathrm{W})$ on the basis of (a) Władysławowo pit and its outskirts, and (b) Jastarnia pit and its outskirts (O- pit's outskirt, S1-pit's shallow slopes, S2- pit's deep slopes, D- bottom of the pit). 


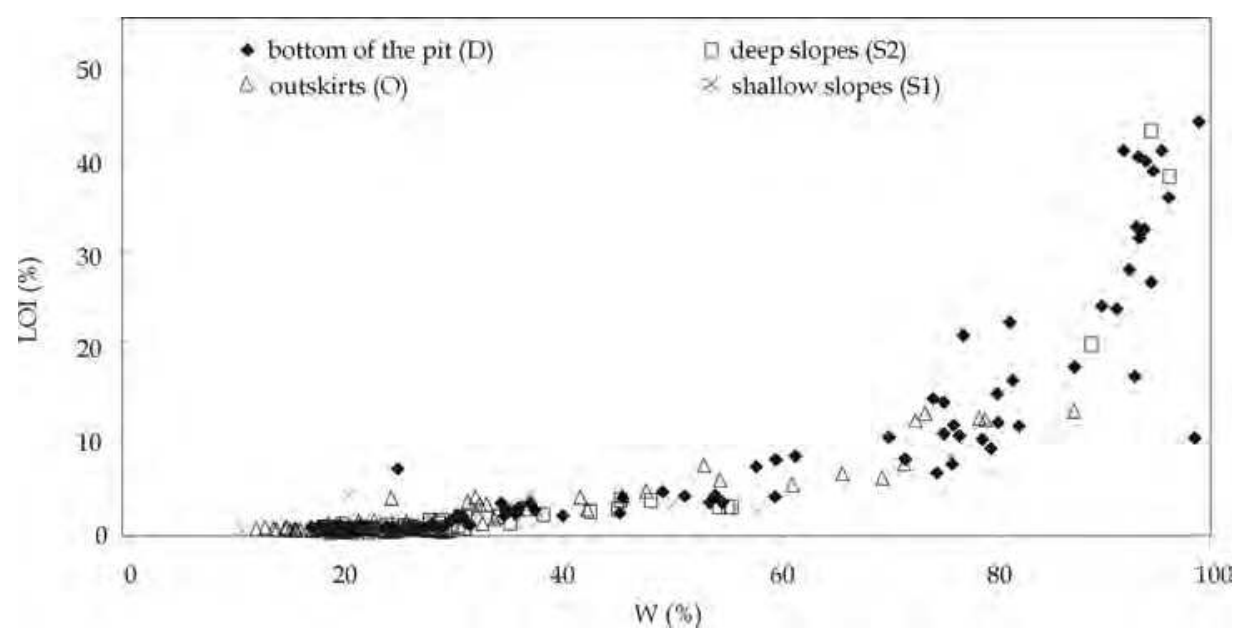

Fig. 8. Relationship between moisture content (W) and lost of ignition (LOI) in sediment.

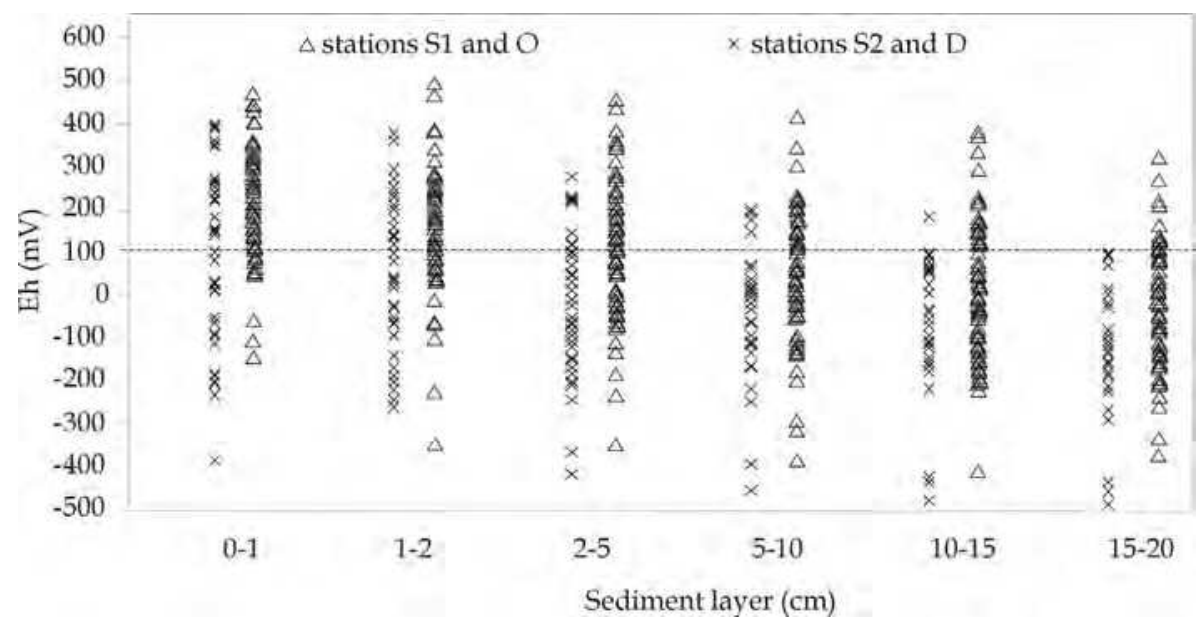

Fig. 9. Redox potential in particular sediment layers in the deepwater part of the dredge pits (stations S2 and D) and at the outskirts of the pits and shallow part of their slopes (stations $\mathrm{O}$ and S1) (dashed line marks the Eh value of $100 \mathrm{mV}$, which is a threshold of reductive conditions (Boyd, 1995).

Generally sediments at outskirts of the pits were characterized by low carbon and total nitrogen content as well as low chl $a$ and pheophytin concentration. Obtained values did not differ from those reported in literature for similar sediment types (Burska et al., 1999).

Among outskirts of all investigated pits, the outskirts of the Władysławowo and Kuźnica II dredge pits were characterized by the higher contents of organic carbon, total nitrogen and photosynthetic pigments (ANOVA Kruskal-Wallis test, $\mathrm{p}<0.05$ ). In the case of sediment 
from the Kuźnica II pit, this finding is connected to the location of its outskirt within the natural pit Kuźnica Hollow (Fig. 2). The increased values of chemical parameters measured in sediment in this location are connected to the natural sedimentation processes and the accumulation of organic matter.

Values of $\mathrm{C}_{\mathrm{org}} / \mathrm{N}_{\text {tot }}$, chl $a /\left(\mathrm{chl} a+\right.$ pheo), and $\mathrm{C}_{\mathrm{org}} /(\mathrm{chl} a+$ pheo) ratios indicate the differences in quality of organic matter in sediments in the study area (Tab. 2). Strongly decomposed organic matter occurred in the deepest part of the dredging pits (stations D). It was manifestated mainly by $\operatorname{chl} a /(\operatorname{chl} a+$ pheo) ratio.

Organic matter in sediments from the outskirts of the Władysławowo dredge pit displayed statistically significant higher molar $\mathrm{C}_{\text {org }} / \mathrm{N}_{\text {tot }}$ ratio (ANOVA Kruskal-Wallis test, $\mathrm{p}<0,05$ ) and higher value of $\mathrm{C}_{\mathrm{org}} /(\mathrm{chl} a+$ pheo) ratio (ANOVA Kruskal-Wallis test, $\mathrm{p}<0,05$ ) in comparison to the outskirts of other pits. In the case of sediments sampled from the deepest part of dredge pits difference in organic matter quality was demonstrated by $\mathrm{C}_{\mathrm{org}} /(\mathrm{chl}$ $a+$ pheo) ratio only. The highest value of this ratio was noted in Władysławowo pit.

Organic carbon and total nitrogen concentration was decreasing with the increasing sediment depth (Fig. 11). Chl $a$ and pheophytin concentrations reached the highest values in samples of surficial sediments $(0-2 \mathrm{~cm})$. In deeper sediment layers the content of $\mathrm{chl} a$ and pheo decreased in a stepwise fashion to reach a stable level in the 5-10 cm layer.

\section{Discussion}

\subsection{An extent of deep dredging impact}

It has been assumed, that conditions at the outskirts of each the dredge pit represent natural environment, and the differences between pit and its outskirts are an effect of deep dredging. In order to assess the extent of geochemical changes in each pit, the Mann-Whitney $U$ test $(\mathrm{p}<0,05)$ has been used to compare selected geochemical parameters (W, LOI Eh, $\mathrm{pH}$ and phosphorus content in sediment) between the dredge pits and their outskirts. Then, statistically significant cases were summed up for each the dredge pit. Similar procedure was used to appraise the season influence on the extent of conditions changes in the pits due to deep dredging (cases with significant changes were summed up for each season).

Significant differences between the outskirts and subsequently: shallow slope, deep slope and deepest part of the dredge pit were observed in 23, 31 and $61 \%$ of the cases, respectively. This indicates that the most vulnerable for geochemical condition changes resulting from deep dredging was the deepwater part of the dredge pits. This confirms previous findings (Bolałek et al. 1996).

Most prevalent changes between the pits and their outskirts were observed in the Władysławowo area (Fig. 12a). Number of changes in the case of Chałupy and Kuźnica I areas was similar, and greater than in the Kuźnica II and Jastarnia regions (Fig. 12a). Among analyzed parameters, the most frequently impacted by deep dredging was moisture content and loss on ignition (Fig. 12a). These parameters reflects the water dynamic and consequently conditions of sediment deposition (Håkanson et al. 2003, Jönsson et al. 2005). High moisture content and loss on ignition, observed in deep part of the dredge pits (Tab. 1, Fig. 7), are characteristic for areas of low water dynamics, where deposition of fine particles takes place, while low values are characteristic for areas where high water dynamics prevents or inhibits settling of those particles. Obtained results indicate, that deep dredging has weakened water dynamics in the area of the dredge pits which enabled the deposition of fine sediments in their deepwater parts (Fig. 6) and favored organic matter accumulation (Tab. 2). 


\begin{tabular}{|c|c|c|c|c|c|c|c|c|}
\hline & & $\mathrm{n}^{1}$ & Min. $^{2}$ & Max. $^{3}$ & Mean & Md. ${ }^{4}$ & $\mathrm{Q}_{\mathrm{L}^{5}}$ & $Q_{U^{6}}$ \\
\hline \multirow{7}{*}{ 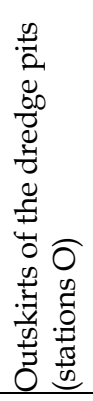 } & W & 215 & 11 & 42 & 20 & 19 & 18 & 20 \\
\hline & LOI & 215 & 0,03 & 6,03 & 0,42 & 0,27 & 0,19 & 0,42 \\
\hline & $P_{\text {tot }}$ & 216 & 1,5 & 13,3 & 7,9 & 7,9 & 6,9 & 9,1 \\
\hline & $P_{\text {inorg }}$ & 214 & 0,1 & 8,3 & 5,7 & 5,7 & 5,1 & 6,4 \\
\hline & $P_{\text {org }}$ & 215 & 0,2 & 6,3 & 2,3 & 2,2 & 1,7 & 2,8 \\
\hline & Eh & 211 & -415 & 489 & 104 & 112 & -15 & 234 \\
\hline & $\mathrm{pH}$ & 206 & 5,04 & 8,22 & 6,92 & 6,83 & 6,67 & 7,20 \\
\hline \multirow{7}{*}{ 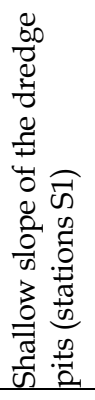 } & W & 118 & 10 & 75 & 23 & 21 & 19 & 23 \\
\hline & LOI & 118 & 0,08 & 9,87 & 0,81 & 0,37 & 0,26 & 0,79 \\
\hline & $P_{\text {tot }}$ & 118 & 5,1 & 21,7 & 8,5 & 8,3 & 7,1 & 9,6 \\
\hline & $P_{\text {inorg }}$ & 118 & 3,2 & 10,4 & 5,7 & 5,7 & 5,1 & 6,4 \\
\hline & $P_{\text {org }}$ & 118 & 0,0 & 11,3 & 2,8 & 2,6 & 2,0 & 3,1 \\
\hline & Eh & 118 & -344 & 432 & 62 & 94 & -46 & 173 \\
\hline & $\mathrm{pH}$ & 117 & 5,01 & 8,16 & 6,87 & 6,93 & 6,55 & 7,21 \\
\hline \multirow{7}{*}{ 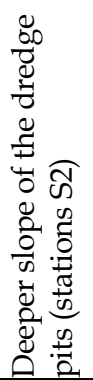 } & W & 114 & 18 & 95 & 26 & 22 & 20 & 25 \\
\hline & LOI & 114 & 0,10 & 42,95 & 1,58 & 0,52 & 0,27 & 0,85 \\
\hline & $P_{\text {tot }}$ & 111 & 4,0 & 87,0 & 10,3 & 8,4 & 7,1 & 9,6 \\
\hline & $P_{\text {inorg }}$ & 111 & 3,9 & 48,4 & 6,6 & 5,9 & 5,1 & 6,5 \\
\hline & $P_{\text {org }}$ & 112 & 0,0 & 58,8 & 3,7 & 2,6 & 2,0 & 3,2 \\
\hline & Eh & 112 & -495 & 385 & 2 & 10 & -115 & 136 \\
\hline & $\mathrm{pH}$ & 108 & 5,95 & 8,41 & 6,96 & 6,95 & 6,66 & 7,29 \\
\hline \multirow{7}{*}{ 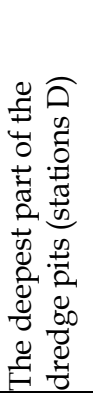 } & W & 92 & 18 & 98 & 54 & 50 & 26 & 81 \\
\hline & LOI & 92 & 0,09 & 44,00 & 10,08 & 3,67 & 0,91 & 15,50 \\
\hline & $P_{\text {tot }}$ & 90 & 1,7 & 71,9 & 22,1 & 13,8 & 8,7 & 33,0 \\
\hline & $P_{\text {inorg }}$ & 90 & 1,3 & 42,9 & 13,3 & 8,9 & 5,7 & 18,1 \\
\hline & $P_{\text {org }}$ & 90 & 0,0 & 44,7 & 8,8 & 3,7 & 2,5 & 13,4 \\
\hline & Eh & 88 & -465 & 393 & -55 & -82 & -192 & 79 \\
\hline & $\mathrm{pH}$ & 86 & 5,23 & 8,07 & 6,85 & 6,88 & 6,45 & 7,26 \\
\hline
\end{tabular}

${ }^{1}$ number of observation; ${ }^{2}$ minimum; ${ }^{3}$ maximum; ${ }^{4}$ median; ${ }^{5}$ lower quartile, ${ }^{6}$ upper quartile

Table 1. Outcome of statistical analysis of geochemical parameters in sediment $(0-20 \mathrm{~cm})(\mathrm{W}-\%$ moisture content, LOI - $\%$ - loss on ignition, $\mathrm{P}_{\text {tot }}, \mathrm{P}_{\text {inorg, }} \mathrm{P}_{\text {org }}-\mu \mathrm{mol} \mathrm{g}-1$ d.w.,- total, inorganic and organic phosphorus content, Eh-mV - redox condition and $\mathrm{pH}$ ) in the study area. 


\begin{tabular}{|c|c|c|c|c|c|c|c|c|}
\hline & & $\mathrm{n}^{1}$ & Min. $^{2}$ & Max. ${ }^{3}$ & Mean & $\mathrm{Md}^{4}$ & $\mathrm{Q}_{\mathrm{L}}^{5}$ & $\mathrm{Q}_{\mathrm{U}^{6}}$ \\
\hline \multirow{7}{*}{ 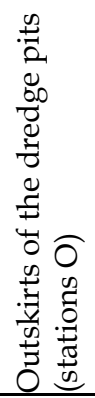 } & $\mathrm{C}_{\text {org }}$ & 221 & 0,21 & 51,56 & 2,39 & 1,05 & 0,59 & 1,87 \\
\hline & $\mathrm{N}_{\text {tot }}$ & 221 & 0,01 & 5,73 & 0,29 & 0,14 & 0,08 & 0,21 \\
\hline & $\operatorname{chl} a$ & 230 & 0,03 & 6,07 & 0,64 & 0,21 & 0,09 & 0,48 \\
\hline & pheo & 230 & 0,03 & 120,82 & 2,75 & 1,11 & 0,60 & 1,95 \\
\hline & $\mathrm{C}_{\text {org }} / \mathrm{N}_{\text {tot }}$ & 215 & 3,3 & 48,0 & 10,9 & 9,3 & 7,2 & 12,9 \\
\hline & $\operatorname{chl} a /(\operatorname{chl} a+$ pheo $)$ & 220 & 1,2 & 90,7 & 23,0 & 17,6 & 9,5 & 30,4 \\
\hline & $\mathrm{C}_{\text {org }} /(\mathrm{chl} a+$ pheo $)$ & 222 & 86 & 6836 & 1059 & 741 & 362 & 1286 \\
\hline \multirow{7}{*}{ 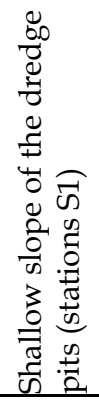 } & $\mathrm{C}_{\text {org }}$ & 110 & 0,38 & 5,46 & 1,54 & 1,20 & 0,84 & 2,09 \\
\hline & $\mathrm{N}_{\text {tot }}$ & 110 & 0,05 & 0,61 & 0,21 & 0,18 & 0,11 & 0,27 \\
\hline & $\operatorname{chl} a$ & 113 & 0,04 & 5,47 & 0,68 & 0,26 & 0,14 & 0,64 \\
\hline & pheo & 113 & 0,06 & 15,44 & 2,42 & 1,92 & 1,20 & 2,93 \\
\hline & $\mathrm{C}_{\text {org }} / \mathrm{N}_{\text {tot }}$ & 107 & 3,0 & 37,4 & 9,84 & 8,78 & 6,6 & 12,2 \\
\hline & $\operatorname{chl} a /(\operatorname{chl} a+$ pheo $)$ & 113 & 1,3 & 65,7 & 18,5 & 14,4 & 7,9 & 25,6 \\
\hline & $\mathrm{C}_{\mathrm{org}} /(\mathrm{chl} a+$ pheo $)$ & 110 & 72 & 14545 & 856 & 536 & 310 & 821 \\
\hline \multirow{7}{*}{ 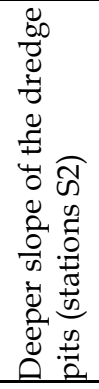 } & $\mathrm{C}_{\text {org }}$ & 105 & 0,31 & 105,92 & 6,10 & 1,65 & 0,96 & 3,21 \\
\hline & $\mathrm{N}_{\text {tot }}$ & 105 & 0,02 & 12,18 & 0,75 & 0,23 & 0,14 & 0,45 \\
\hline & $\operatorname{chl} a$ & 105 & 0,00 & 35,25 & 1,66 & 0,38 & 0,17 & 1,23 \\
\hline & pheo & 105 & 0,11 & 184,79 & 8,37 & 3,00 & 1,83 & 4,50 \\
\hline & $\mathrm{C}_{\mathrm{org}} / \mathrm{N}_{\mathrm{tot}}$ & 101 & 3,0 & 34,7 & 9,7 & 8,5 & 6,9 & 10,6 \\
\hline & $\operatorname{chl} a /(\operatorname{chl} a+$ pheo $)$ & 102 & 0,8 & 47,5 & 16,4 & 14,4 & 6,6 & 22,0 \\
\hline & $\mathrm{C}_{\text {org }} /(\mathrm{chl} a+$ pheo $)$ & 96 & 48 & 6905 & 632 & 475 & 270 & 681 \\
\hline \multirow{7}{*}{ 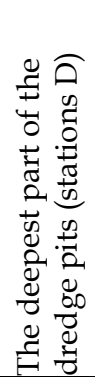 } & $\mathrm{C}_{\text {org }}$ & 95 & 0,21 & 168,50 & 35,12 & 19,98 & 2,42 & 51,02 \\
\hline & $\mathrm{N}_{\text {tot }}$ & 95 & 0,03 & 22,11 & 4,51 & 1,72 & 0,39 & 6,62 \\
\hline & $\operatorname{chl} a$ & 95 & 0,00 & 124,12 & 7,88 & 1,84 & 0,44 & 7,92 \\
\hline & pheo & 95 & 0,11 & 257,13 & 52,39 & 28,31 & 4,16 & 77,85 \\
\hline & $\mathrm{C}_{\mathrm{org}} / \mathrm{N}_{\text {tot }}$ & 95 & 4,5 & 23,1 & 9,8 & 9,2 & 7,7 & 11,1 \\
\hline & $\operatorname{chl} a /(\operatorname{chl} a+$ pheo $)$ & 88 & 0,3 & 43,5 & 12,0 & 11,1 & 7,3 & 14,9 \\
\hline & $\mathrm{C}_{\mathrm{org}} /(\mathrm{chl} a+$ pheo $)$ & 98 & 22 & 8155 & 908 & 561 & 201 & 930 \\
\hline
\end{tabular}

$1-6$ as in Table 1

Table 2. Outcome of statistical analysis of selected organic matter components and indicators of organic matter quality: organic carbon (Corg - $\mathrm{mg} \mathrm{g}^{-1} \mathrm{~d}$.w.), total nitrogen (Ntot - mg g-1 d.w.), chlorophyll $a$ (chl $a-\mu g^{-1}$ d.w.), pheophytin (pheo - $\mu$ g g-1 d.w.), Corg/Ntot, Corg / (chl $a+$ pheo) (\%), chl $a /(\mathrm{chl} a+$ pheo) (\%)) in sediment $(0-20 \mathrm{~cm})$. 

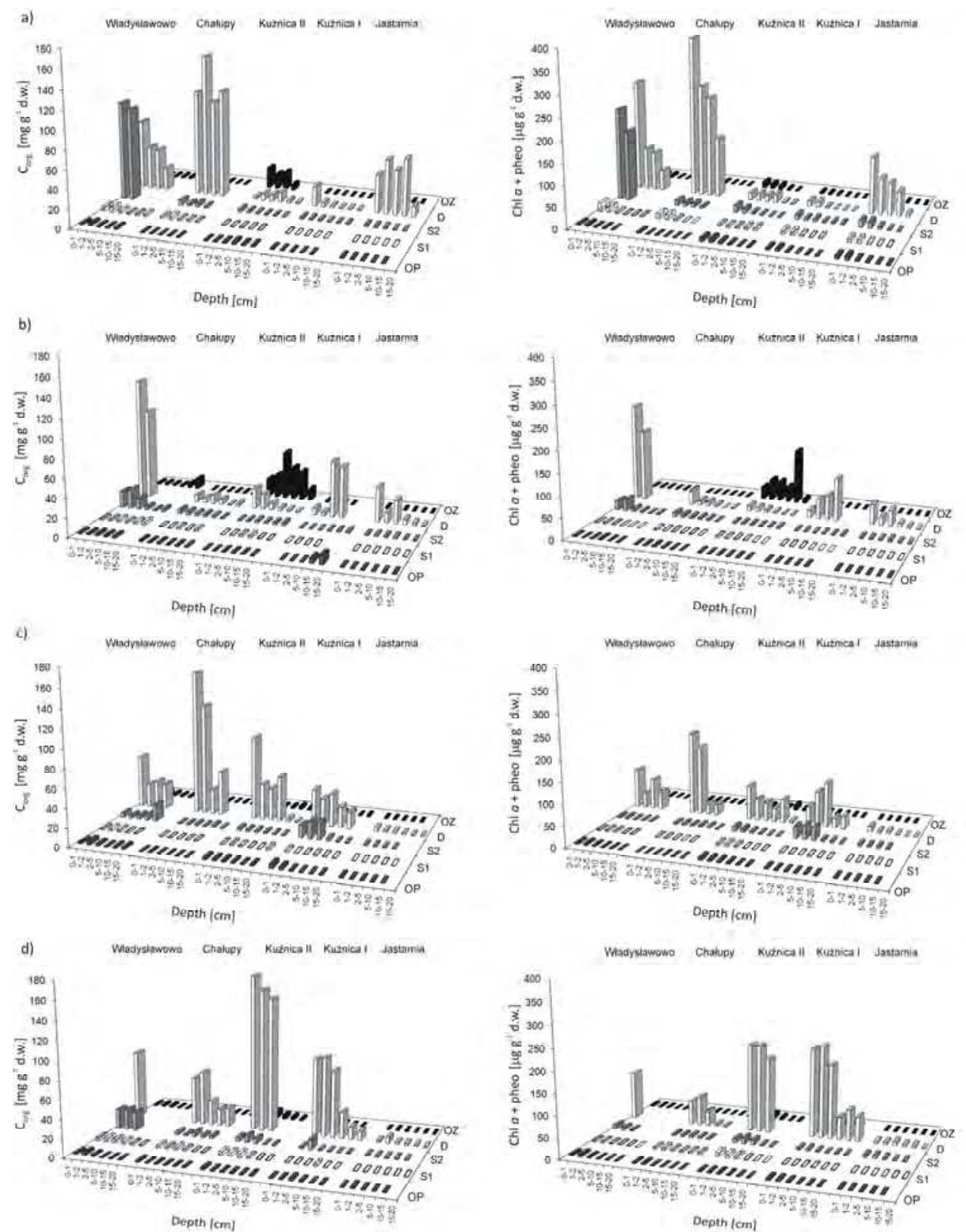

Fig. 10. Organic carbon content (Corg - $\mathrm{mg} \mathrm{g}^{-1} \mathrm{~d}$.w.) and the sum of photosynthetic pigments (chl $a+$ pheo $-\mu \mathrm{g} \mathrm{g}^{-1} \mathrm{~d} . \mathrm{w}$.) in sediments from the dredge pits and their outskirts in a) November-December 2007, b) March 2008, c) May-June 2008 and d) August 2008. (OP - outskirt of the pit, peninsula side, OZ - outskirt of the pit, bay side, S1 - shallow slope of pit, S2 - deep slope of pit, D - bottom of the pit). 

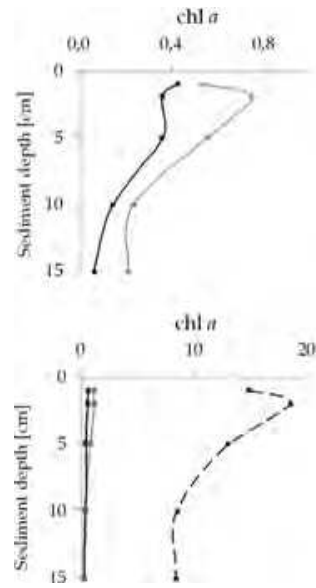
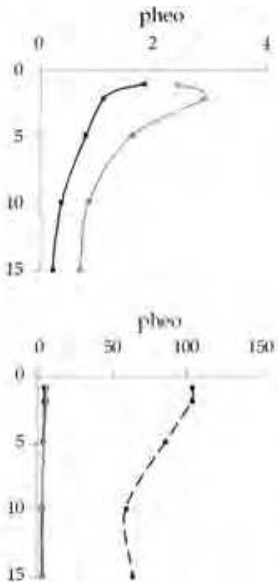
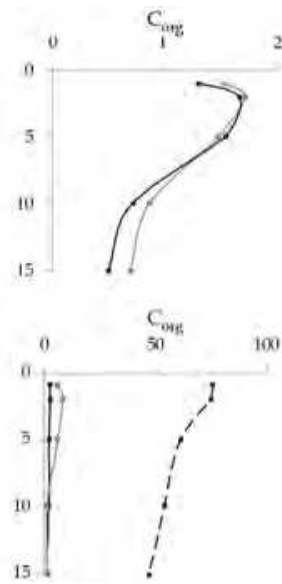
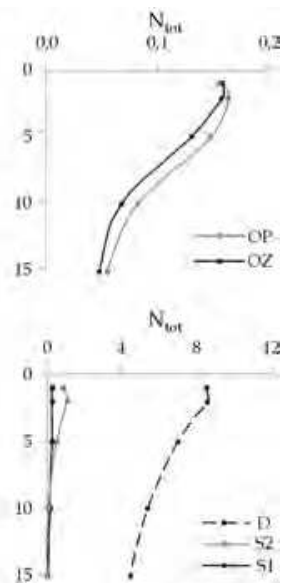

Fig. 11. Sediment profiles of mean concentrations of chlorophyll $a$ (chl $\left.a-\mu \mathrm{g} \mathrm{g}^{-1} \mathrm{~d} . \mathrm{w}.\right)$, pheophytin (pheo - $\mu \mathrm{g} \mathrm{g}^{-1} \mathrm{~d}$.w.), organic carbon ( $\mathrm{C}_{\text {org }}-\mathrm{mg} \mathrm{g}^{-1} \mathrm{~d} . \mathrm{w}$.) and total nitrogen $\left(\mathrm{N}_{\text {tot }}-\mathrm{mg} \mathrm{g}\right.$-1 d.w.) in the dredge pits (stations: S1-pit's shallow slopes, S2- pit's deep slopes, D- bottom of the pit) and their outskirts (stations OP and OZ) in August 2008.

This caused sulfate reduction, and in consequence hydrogen sulfide availability, as well as an increase of ammonia and phosphate concentration in the interstitial waters (Fig. 5). Elevated levels of organic matter associated with dredged sediments and deposition of finegrained sediment in dredge pits have been documented by researchers elsewhere (Johnnston 1981, Nayar et al. 2007, Palmer et al, 2008). In very deep dredge pits such as located in Lake Pontchartrain's, sulfate reduction was dominant process of organic matter degradation (Flocks\&Franze 2002). Also previous studies conducted in Kuźnica II and Władysławowo pits indicated anoxic degradation of organic matter. They also indicated temporal oxygen deficits in the nearbottom waters of the Władysławowo pit (Bolałek et al. 1996, Graca, 2009). During presented study, high concentrations of hydrogen sulfide temporally observed in the dredge pits (Fig. 5) so suggest oxygen deficits in the nearbottom waters. Oxygen was determined in samples of the water collected c. $0.5 \mathrm{~m}$ over bottom, so probably oxygen deficits closer to the sediment surface.

Impact of deep dredging decreased seawards (Fig. 12a) and has been strongest in the Władysławowo pit area characterized with the weakest water dynamics. Weak water dynamics at the Władysławowo sampling site is indicated by a relatively high content of fine sediment fractions at the outskirts of the dredge pit. (Fig. 6). It also corresponds to the highest content of organic carbon and total nitrogen in sediments collected from the pit and its outskirts (Fig. 10). Moreover, high values of $\mathrm{C}_{\mathrm{org}} / \mathrm{N}_{\text {tot }}$ and $\mathrm{C}_{\mathrm{org}} /(\mathrm{chl} / \mathrm{a} /+$ pheo) ratio, which have been observed in this area (Tab. 2), indicate the larger share of terrigenic matter in sediments from Władysławowo as compared to those from other sampling sites.

Factor diminishing the impact of deep dredging in the Kuźnica II pit, could be the vicinity of a natural bottom depression, the Kuźnicka Hollow and the fact that the dredge pit is partially connected with it - which is proved by an up-to-date bathymetry (Fig. 2).

Deep dredging impact on geochemical condition was not clearly seasonally dependent in Jastarnia and Kuźnica I pits. (Fig. 12b). Jastarnia pit is located in the Outer Puck Bay. Kuźnica I pit is situated in the areas characterized with intensive currents, through which 
the water exchange between Inner and Outer Puck Bay occurs. In other dredge impacted regions (Władysławowo, Chałupy, Kuźnica II), located in the Inner Puck Bay, differences were rarely significant in March. In August and November/December an increase of significant differences frequency has been visible in Kuźnica II region (Fig. 12b).
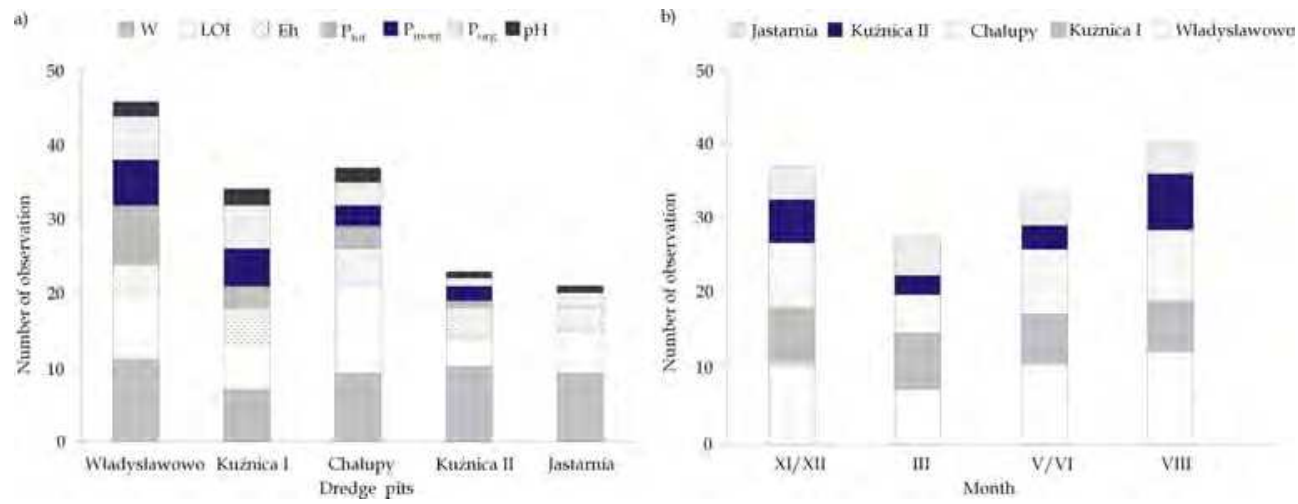

Fig. 12. Number of statistically significant differences in geochemical conditions (MannWhitney $U$ test, $p<0,05$ ) between (a) particular pits and their outskirts (b) dredge pits and their outskirts in particular sampling seasons.

It seems that season influence on the extent of dredging impact depended on pit location and associated water exchange and circulation. The Inner Puck Bay, where season influence was clearly visible, is a shallower, isolated part of the Puck Bay, with hindered water exchange, when compared to the Outer Puck Bay (Nowacki 1993).

The complex interaction of organic matter degradation and increased water dynamics during storms could contribute to the decrease of differences between dredge pits and their outskirts in the cold half year. In consequence, the end of winter is probable a good time to monitor the geochemical conditions in the deep dredging impacted area, because represents "permanent" changes resulting from dredging.

\subsection{Deep dredging impact on nitrogen and phosphorus internal loading}

A complex interplay of high supply of organic matter to the sediment, hydrogen sulfide production and lost of benthic organisms diminish sediment ability to phosphorus storage (Gächter\&Müller 2003, Gunnars at al. 2002, Karlson et al. 2007), decrease coupled nitrification/denitryfication (Sørensen et al., 1980, Karlson et al. 2005, 2007) and increase ammonia regeneration (Kelly et al. 1985; Kemp et al. 1990). As a result deep dredging potentially influences nitrogen and phosphorus dynamic and increases their internal loading in the dredge pit areas. Previous studies, conducted in the Puck Bay, indicated a decrease of phosphorus accumulation to its removal ratio from 9,3 in natural bottom to 2,2 in the Kuźnica II dredge pit, and a decrease of denitrification to ammonification ratio from 6,3 in natural bottom to 0,2 in the dredge pit area (Graca et al. 2004).

Ammonia and phosphate are main components of nitrogen and phosphorus benthic fluxes in the study area, as well as in other eutroficated regions of the Baltic Sea (Conley et al. 1997; Graca et al. 2004, Pitkänen et al. 2001). In order to assess potential enhancement of eutrofication due to dredge pits impact on nutrient dynamic, their benthic fluxes have been 
estimated in and around the dredge pits basing on Fick's first law. Calculation's details were the same, as in previous study conducted in Kuźnica II dredge pit (Graca et al. 2004). Nutrients loadings released from the sediments were calculated, considering the surface of each depth in the dredge pits (calculated by using Surfer 8 ) and fluxes seasonal variability. Both actual ( $\mathrm{P}_{\mathrm{ac},}, \mathrm{N}_{\mathrm{ac}}$ ) and potential ( $\mathrm{P}_{\text {pot., }} \mathrm{N}_{\text {pot. }}$ ) loads have been calculated, where potential load denotes the load in situation, when the conditions in the dredge pits would be identical to that found in their outskirts (Tab. 3). From the difference between the actual and potential loads, a surplus of $\mathrm{N}$ and $\mathrm{P}$ removed to water due to deep dredging has been calculated. This is only a rough estimation, because Fick's first law allows only diffusive fluxes. Not include mineralization of organic matter on the surface of sediment and influences of water dynamics and benthic organisms on the benthic fluxes (Forja \& Gómez-Parra, 1998; Val Klump \& Martens, 1983; Zabel et al., 2000). Therefore fluxes at the outskirts and shallow pit's slopes are probable underestimated. In deepwater part of dredge pits, effects of benthic organisms and turbulent diffusion are potentially limited. As the result, fluxes due to molecular diffusion are probably the major component of the total nutrient exchange in this area. However, when sediments are rich in organic matter and the nearbottom water contain oxygen, as in the dredge pits deepest area, fluxes of phosphate and ammonia calculated based on Fick's first law could have been overestimated. The reason is phosphate precipitation and/or adsorption, as well as coupled nitrification/denitrification at the sediment surface. On the other hand, permanent presence of hydrogen sulfide in deepwater part of dredge pits, potentially inhibit nitrification and in turn, hamper denitrification (Dollhopf et al. 2005, Herbert 1999). Moreover, hydrogen sulfate availability limits the sediment phosphorus sorption capacity. Formations of FeS and FeS2 results in removal of the phosphates previously bound to iron oxyhydroxide despite oxygenated nearbottom water (e.g. Gähter\&Müler, 2003). Though presented estimations are rough, they indicate the scale of the problem. Increase of internal $\mathrm{N}$ and $\mathrm{P}$ loadings has been observed in all dredge pits (Tab. 3). Surplus of $\mathrm{N}$ and $\mathrm{P}$ removed to water column has been the highest in the area of the biggest pit - Kuźnica II. However, the ratio of actual to potential loadings indicate, that the Władysławowo pit was the area, where internal loading has been intensified the most (Tab. 3).

\begin{tabular}{llllllllll}
\hline \multirow{2}{*}{ dredge pit } & \multirow{2}{*}{ area $\left(\mathrm{m}^{2}\right)$} & \multicolumn{3}{l}{ load $\left(\mathrm{kg} \mathrm{y}^{-1}\right)$} & & \multicolumn{5}{c}{ loads ratio } \\
\cline { 3 - 10 } & & $\mathrm{P}_{\text {ac. }}$ & $\mathrm{P}_{\text {pot. }}$ & $\Delta \mathrm{P} 1)$ & $\mathrm{N}_{\mathrm{ac}}$ & $\mathrm{N}_{\text {pot. }}$ & $\left.\Delta \mathrm{N}^{2}\right)$ & $\mathrm{P}_{\text {ac. }} / \mathrm{P}_{\text {pot. }}$ & $\mathrm{N}_{\text {ac. }} / \mathrm{N}_{\text {pot. }}$ \\
\hline Władysławowo & 6519 & 0,4 & 0,03 & 0,4 & 4,1 & 0,1 & 4,0 & 13,3 & 40,1 \\
Chałupy & 205068 & 5,3 & 0,9 & 4,4 & 54,3 & 4,7 & 49,6 & 5,8 & 11,6 \\
Kźnica II & 873874 & 23,3 & 7,0 & 16,3 & 262,1 & 56,3 & 205,8 & 3,3 & 4,6 \\
Kuźnicy I & 187389 & 2,7 & 2,0 & 0,7 & 25,5 & 3,8 & 21,7 & 1,3 & 6,7 \\
Jastarnia & 220315 & 2,2 & 1,6 & 0,6 & 12,7 & 11,1 & 1,6 & 1,4 & 1,1 \\
\hline sum & 1493165 & 33,9 & 11,5 & 22,3 & 358,8 & 76,0 & 282,8 & & \\
\hline
\end{tabular}

1) - $\Delta P=P_{\text {ac. }}-P_{\text {pot. }}$ 2) - $\Delta N=N_{\text {ac. }}-N_{\text {pot. }}$

Table 3. Phosphorus ( $\left.\mathrm{P}_{\mathrm{ac}}\right)$ and nitrogen $\left(\mathrm{N}_{\mathrm{ac}}\right.$ ) loadings released from the sediments of particular dredge pits and loadings of those elements which would have been released $\left(\mathrm{P}_{\text {pot. }}\right.$ $\mathrm{N}_{\text {pot. }}$, if the conditions in the dredge pits would be identical to those observed at their outskirts. 
In the contrary, Jastarnia pit was the area, where internal loading has been intensified insignificantly. From sediments of all the dredge pits a surplus of c. $22 \mathrm{~kg}$ of P and c. $238 \mathrm{~kg}$ of $\mathrm{N}$ was removed annually into the water column. Such values are trivial in respect to for example external loadings of $\mathrm{N}$ and $\mathrm{P}$ into the Puck Bay $\left(16,1 \mathrm{t} \mathrm{P}^{-1}\right.$ and $18 \mathrm{t} \mathrm{N} \mathrm{a} \mathrm{a}^{-1}$, Pempkowiak, 1997). This is connected to relatively small dredge pit's area $\left(1,49 \mathrm{~km}^{2}\right)$. Therefore dredge pits create an important problem, but rather in scale of coastal areas of the Hel Peninsula where pits are located, than in scale of the whole Puck Bay.

Water residence time is important factor influencing susceptibility to eutrophication in aquatic ecosystems (Wulff \& Stigebrandt 1989, Nedwell et al. 1999, Dettman 2001, Savchuk \& Wulff 2007). Nitrogen and phosphorus loadings released from sediments probable can affect the environment more in the Inner Puck Bay, because of longer water residence time than in the Outer Puck Bay (Nowacki 1993) and consequently, longer N and P residence times in this area. It is worth mentioning, that hydrodynamic studies conducted in the frame of current project (not published) showed that the dredge pits additionally slightly hinder the water exchange between Inner and Outer Puck Bay.

\section{Conclusions}

All the dredge pits in the Puck Bay create sink for organic matter and fine-grained sediments. As the result hydrogen sulfide production has been stimulated, especially in deepwater parts of pits. Important implication of hydrogen sulfide production could be restricted pit's recolonization by benthos organisms. Moreover, the complex interplay of hydrogen sulfide availability and lost of benthic organisms could probable influence nitrogen and phosphorus dynamic. Rough estimations showed significant increase of internal $\mathrm{N}$ and $\mathrm{P}$ loadings in some of the dredge pits. Due to their relatively small area $\left(1,49 \mathrm{~km}^{2}\right)$, surplus of $\mathrm{N}$ and $\mathrm{P}$ annually released from the pit's sediments (several hundred kilos of nitrogen and a dozen or so kilos of phosphorus) create problem rather in scale of coastal areas of the Hel Peninsula where pits are located, than in scale of the whole Puck Bay.

Deep dredging impact on geochemical condition was the most pronounced and clearly seasonal dependent in a shallower, isolated part of the Puck Bay. In this region of the bay organic matter degradation in sediment and increased water dynamics during storms, decrease differences in geochemical conditions between dredge pits and their outskirts in the cold half year.

\section{Acknowledgement}

Research was conducted within the project entitled "Creation of recultivation program for post-dredging area in Puck Bay (R 1404203) financed by the polish Ministry of Science and Higher Education and realized by Maritime Institute in Gdańsk.

\section{References}

Bolałek J., Falkowska L. \& Korzeniewski K. (1993). Hydrochemia Zatoki, In: Zatoka Pucka, K. Korzeniewski, pp. 222-281, Fundacja Rozwoju Uniwersytetu Gdańskiego, Gdańsk 
Bolałek J., Jankowska H., Łęczyński L., Frankowski L. \& Podgórska B. (1996). Geological, geochemical and bacteriological conditions in the postdredging pit in Puck Bay. (Southern Baltic, Poland). Oceanological Studies, XXV (3), pp. 111122

Boyd, C.E. (1995). Bottoms soils, sediment and pond aquaculture. Chapman\&Hall, New York Bradtke K. \& Urbański, J. (2008). (http:/ / pim.iopan.gda.pl/ZatokaPucka).

Burska D., Frankowski L. \& Bolałek J. (1999). Temporal variability in the chemical composition of bottom sediments in the Pomeranian Bay (Southern Baltic). Oceanology, 41, pp. 445-459

Burska D. (2010). Analiza elementarna (CHNS), In: Fizyczne, biologiczne i chemiczne badania morskich osadów dennych, J. Bolałek, pp. 289-295, Wydawnictwo Uniwersytetu Gdańskiego, Gdańsk

Ciszewski P. \& Kruk-Dowgiałło L. (1992). Ecological requirements for conducting the dredging works in the region of Chałupy and Kuźnica on the open sea side of the Hel Peninsula. Typescript (in Polish)

Conley, D.J., Stockenberg, A., Carman, R., Johnstone, R.W., Rahm, L. \& Wulff, F. (1997). Sediment-water nutrient fluxes in the Gulf of Finland, Baltic Sea. Estuarine, Coastal and Shelf Science, 45, pp. 591-598

Desprez, M. (2000). Physical and biological impact of marine aggregate extraction along the French coast of the Eastern English Channel: short- and long-term post-dredging restoration. ICES Journal of Marine Science, 57, pp. 1428-1438

Dettmann, E.H. (2001). Effect of water residence time on annual export and denitrification of nitrogen in estuaries: A model analysis. Estuaries, 24(4), pp. 481-490

Dollhopf, S.L., Hyun, J., Smith, A.C., Adams, H.J., O’Brien, S. \& Kostka, J.E. (2005). Quantification of ammonia-oxidizing bacteria and factors controlling nitrification in salt marsh sediments. Applied and Environmental Microbiology, 71(1), pp. 240246

Flocks \& Franze (2002). Environmental Issues-Dredge Pit Characterization, Environmental Atlas of the Lake Pontchartrain Basin, (http://pubs.usgs.gov/of/2002/of02206/env-issues/pit-characterization.html)

Forja J.M. \& Gómez-Parra A. (1998). Measuring nutrient fluxes across the sediment-water interface using benthic chambers. Marine Ecology and Progress Series, 164, pp. 95105

Froelich P.N., Arthur M.A., Burnett W.C., Deakin M., Hensley V. Jahnke R., Kaul L., Kim K.H., Roe K., Soutar A. \& Vathakanon C. (1988). Early diagenesis of organic matter in Peru continental margin sediments: phosphorite precipitation. Marine Geology, 80, pp. 309-343

Gächter R. \& Müller B. (2003) Why the phosphorus retention of lakes does not necessarily depend on the oxygen supply to their sediment surface. Limnology and Oceanography, 48(2), pp. 929-933

Golterman H.L. (1975). Physiological limnology. Elsevier Scientific Pub. Co., N.Y. 
Graca B., Burska D., Dudkowiak M., Jędrasik J., Kowalewski M., Łęczyński L., Łukawska K., Szymelfenig M. \& Zarychta A. (2003). Ocena wptywu wyrobisk porefulacyjnych na zmiany ekosystemu Zatoki Puckiej. RAPORT Projektu KBN 6PO4E 01709 (in Polish)

Graca B., Burska D. \& Matuszewska K. (2004). The impact of dredging deep pits on organic matter degradation in sediments. Water Air and soil Polution, 158, pp. 237259

Graca B., Witek, Z., Burska, D., Białkowska, I., Pawelec, A., \& J. Bolałek (2006). Porewater's nutrients (phosphate, ammonia and silicate) in southern Baltic Sea. Oceanological and Hydrobiological Studies, XXXV (3), pp. 237-25

Graca B. \& Dudkowiak M. (2007). Microbiological changes in environment caused by deep dredging. A case study: post-dredging pit Kuźnica II. Oceanological and Hydrobioogical Studies, XXXVI (1), pp. 17-27

Graca, B. (2009). The dynamics of nitrogen and phosphorus transformations at the sediment-water interface in the Gulf of Gdańsk, Wydawnictwo UG, Gdańsk (in polish with English abstract)

Grasshoff K., Ehrhardt M. \& Kremling K. (1983). Methods of sea water analysis, Verlag Chem., Weinheim

Gunnars, A. Blomqvist, S., Johansson, P. \& Andersson, C. (2002). Formation of Fe(III) oxyhydroxide colloides in freshwater and brackish seawater, with incorporation of phosphate and calcium. Geochimica et Cosmochimica Acta, 66, pp. $745-758$

Håkanson L., Lundin L.-C., Savchuk O., Ionov V., Musielak S. \& Furmańczyk K. (2003). The Baltic Sea, In: L. Ryden, P. Migula, M. Andersson, pp. 120-147, Environmental Science, The Baltic University Press, Uppsala

Hedges J.I. \& Stern J.H. (1984). Carbon and nitrogen determinations of carbonate containing solids. Limnol. Oceanogr., 29, pp. 657-663

Herbert, R. A. (1999). Nitrogen cycling in coastal marine ecosystems. FEM Microbiol. Rev, 23, pp. $563-590$

Johnnston S.A. Jr (1981). Estuarine dredge and fill activities: A review of impacts. Environmental Management, 5 (5), pp. 427-440

Jönsson A., Danielsson Á. \& Rahm L. (2005). Bottom type distribution based on wave friction velocity in the Baltic Sea. Continental Shelf Research, 25, pp. 419-435

Karlson, K., Hulth, S. \& Ringdahl, K., Rosenberg, R. (2005). Experimental recolonisation of Baltic Sea reduced sediments: survival of benthic macrofauna and effects on $\mathrm{N}$ and P biogeochemistry. Marine Ecology Progress Series, 294, pp. 35-49

Karlson K., Bonsdorff E. \& Rosenberg R. (2007). The impact of benthic macrofauna for nutrient fluxes from Baltic Sea sediments. Ambio, 36 (2/3), pp. 1-7

Kemp, W.M., Sampou, P., Caffrey, J. \& Mayer, M. (1990). Ammonium recycling versus denitrification in Chesapeak Bay Sediments. Limnology and Oceanography, 35 (7), pp. 1545-1563

Kelly J.R., Berounsky V.M., Nixon S.W. \& Oviatt C.A. (1985). Benthic-pelagic coupling and nutrient cycling across an experimental eutrophication gradient. Marine Ecology Progress Series, 26, pp. 207-219 
Maa, J. P.Y., Hobbs, C.H., Kim S.C. \& Wei, E. (2004). Possible impacts on physical oceanpgraphic processes by cumulative sand mining offshore of Maryland and Delaware. Journal of Coastal Research, 20 (1), pp. 44-60

Maksymowska D., Degradacja materii organicznej w toni wodnej $i$ osadach dennych Zatoki Gdańskiej, Instytut Oceanografii UG, Gdynia (in Polsih)

Nayar S., · Miller D.J., Hunt A. \&· Goh B.P.L. Chou L.M. (2007). Environmental effects of dredging on sediment nutrients, carbon and granulometry in a tropical estuary. Environ Monit Assess, 127, pp. 1-13

Nedwell D.B., Jickells T.D., Trimmer M. \& Sanders, R. (1999). Nutrient in estuaries. Advances in Ecological Research, 29, pp. 43-92

Nowacki, J. (1993). Cyrkulacja i wymiana wód, In: Zatoka Pucka, K. Korzeniewski, pp. 181206, Fundacja Rozwoju Uniwersytetu Gdańskiego, Gdańsk

Palmer T.A., Paul A. Montagna P:A. \& Nairn R.B. (2008). The effects of a dredge excavation pit on benthic macrofauna in offshore Louisiana. Environmental Management, 41, pp. 573-583

Pempkowiak J. (1994). Przyczyny katastrofy ekologicznej w rejonie Zatoki Puckiej. Zanieczyszczenie i odnowa Zatoki Gdańskiej, Gdynia, Polska

Pitkänen, H., Lehtoranta J. \& Räike, A. (2001). Internal nutrient fluxes counteract decreases in external load: The case of the estuarial eastern Gulf of Finland, Baltic Sea. Ambio, 30 (4-5), pp. 195-201

Plante-Cuny M. (1974). Evaluation par spectrophotometrie des teneurs en chlorophylle a fonctionelle et en pheopigments des substrats meubles marins. Mission Orstom Nosy-Be, Madagascar, 45, pp. 1-76

Savchuk O. \& Wulff F. (2007). Modeling the Baltic Sea eutrophication in a decision support system. Ambio, 36 (2), pp. 141-148

Sørensen J., Tiedje J.M. \& Fiestone R.B. (1980). Inhibition by sulfide of nitric and nitrous oxide reduction by denitrifying Pseudomonas fluorescens. Applied and Environmental Microbiology, 39, pp. 105-108

Strickland J.D.H. \& ParsonsT.R. (1972). A practical handbook of seawater analysis. Bulletin of the Fisheries Research Board of Canada, 167

Szymelfenig M., Kotwicki L. \& Graca B. (2006). Benthic re-colonization in post-dredging pits in the Puck Bay (the southern Baltic Sea). Estuarine and Coastal Shelf Science, 68, pp. 489-498

Val Klump, J. \& Martens, C.S. (1983). Benthic nitrogen regeneration, In: Nitrogen in the marine environment, E.J., Carpenter, D., Capone, pp. 411-459Academic Press, London

Schindler D.W. \& Vallentyne J.R. (2008). Algal bowl: overfertilization of the world's freshwaters and estuaries, Michigan State Univ Pr

Work P.A., Fehrenbacher F., \& Voulgaris G. (2004). Nearshore impacts of dredging for beach nourishment. Port, Coast., and Oc. Engrg.,130(6), pp. 303-311

Wulff F. \& Stigebrandt A. (1989). A time-dependent budget model for nutrients in the Baltic Sea. Global Biogeochemical Cycle, 3, pp. 63-78 
Zabel M., Hensen C. \& Schlüter M. (2000). Back to the ocean cycles: benthic fluxes and their distribution patterns, In: Marine Geochemistry, H.D., Schulz, M. \& Zabel, pp. 373394, Springer Verlag Berlin-Heidelberg

Urbański \& Solanowska (2009).

http://www.ocean.univ.gda.pl/ oceju/zmiany_polwyspu_helskiego.pdf 


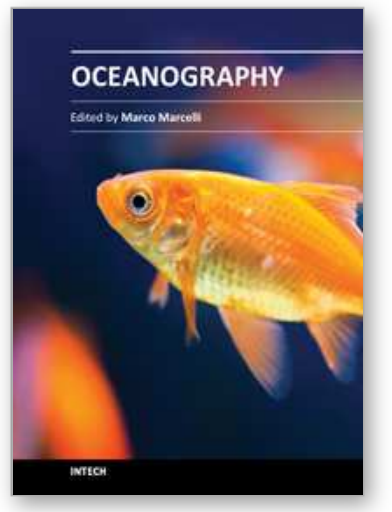

\author{
Oceanography \\ Edited by Prof. Marco Marcelli
}

ISBN 978-953-51-0301-1

Hard cover, 348 pages

Publisher InTech

Published online 23, March, 2012

Published in print edition March, 2012

How inappropriate to call this planet Earth when it is quite clearly Ocean (Arthur C. Clarke). Life has been originated in the oceans, human health and activities depend from the oceans and the world life is modulated by marine and oceanic processes. From the micro-scale, like coastal processes, to macro-scale, the oceans, the seas and the marine life, play the main role to maintain the earth equilibrium, both from a physical and a chemical point of view. Since ancient times, the world's oceans discovery has brought to humanity development and wealth of knowledge, the metaphors of Ulysses and Jason, represent the cultural growth gained through the explorations and discoveries. The modern oceanographic research represents one of the last frontier of the knowledge of our planet, it depends on the oceans exploration and so it is strictly connected to the development of new technologies. Furthermore, other scientific and social disciplines can provide many fundamental inputs to complete the description of the entire ocean ecosystem. Such multidisciplinary approach will lead us to understand the better way to preserve our "Blue Planet": the Earth.

\title{
How to reference
}

In order to correctly reference this scholarly work, feel free to copy and paste the following:

Bożena Graca, Katarzyna Łukawska-Matuszewska, Dorota Burska, Leszek Łęczyński and Jerzy Bolałek (2012). Geochemical Changes in Aquatic Environment Caused by Deep Dredging - A Case Study: The Puck Bay (Baltic Sea), Oceanography, Prof. Marco Marcelli (Ed.), ISBN: 978-953-51-0301-1, InTech, Available from: http://www.intechopen.com/books/oceanography/geochemical-changes-in-aquatic-environment-caused-bydeep-dredging-a-case-study-the-puck-bay-the-bal

\section{INTECH}

open science | open minds

\section{InTech Europe}

University Campus STeP Ri

Slavka Krautzeka 83/A

51000 Rijeka, Croatia

Phone: +385 (51) 770447

Fax: +385 (51) 686166

www.intechopen.com

\section{InTech China}

Unit 405, Office Block, Hotel Equatorial Shanghai

No.65, Yan An Road (West), Shanghai, 200040, China 中国上海市延安西路65号上海国际贵都大饭店办公楼 405 单元

Phone: $+86-21-62489820$

Fax: $+86-21-62489821$ 
(C) 2012 The Author(s). Licensee IntechOpen. This is an open access article distributed under the terms of the Creative Commons Attribution 3.0 License, which permits unrestricted use, distribution, and reproduction in any medium, provided the original work is properly cited. 